\title{
CARRIAGE OF CRYPTOCOCCUS NEOFORMANS IN THE CROPS OF PIGEONS
}

\author{
Z. U. Khan, M. Pal, H. S. Randhawa and R. S. Sandhu \\ Department of Medical Mycology, Vallabhbhai Patel Chest Institute, \\ University of Delhi, Delhi-110007
}

SINCE Emmons (1955) first reported the association of Cryptococcus neoformans with pigeon excreta, similar observations have been made in various parts of the world (Partridge and Winner, 1965; Randhawa, Clayton and Riddell, 1965; Gustin and Kelley, 1971; Gugnani, Gupta and Shrivastav, 1972; Pal, 1975). It is generally believed, however, that the pigeon is not a host to, or reservoir of, this fungus although it may serve as a mechanical carrier (Ajello, 1967; Littman and Borok, 1968). A recent paper by Swinne-Desgain (1974), reporting a fairly high frequency of isolations of $C$. neoformans from the crops of pigeons and implicating the bird as a reservoir, prompted us to re-investigate the association of this fungus with pigeons.

\section{MATERIALS AND METHODS}

Birds studied. The main focus of the study was the Charity Bird Hospital, Chandni Chowk, Delhi, maintaining over 600 pigeons. The hospital comprised two spacious rooms on the first floor of a temple. While the sick or injured pigeons were housed individually in cages, the healthy birds were kept free inside the rooms. Old and dry excreta were widely scattered, and accumulations of faeces were particularly noticeable inside the cages. Pigeons trapped from the University of Delhi Campus were also examined for C. neoformans carriage in the crop.

Isolations. Crop swabs from 286 and crop washings from 33 live pigeons were collected after cleaning the beaks with alcohol. The crops were gently swabbed with sterile, moistened cotton swabs; these were streaked directly on slants of Staib's Guizotia abyssinica seed medium, prepared as described by Randhawa, Staib and Blisse (1973). Crop washings were obtained by injecting $10 \mathrm{ml}$ of normal saline $(0.85 \% \mathrm{NaCl})$ slowly into the crop, through a thin polythene tube attached to an 18-gauge needle and syringe. The crop of the bird was massaged gently for a few minutes before the washings were withdrawn. The material was centrifuged at 3000 r.p.m. for $15 \mathrm{~min}$. and the deposit was cultured. Portions of the contents of the proventriculus, gizzard, small intestine, large intestine and crop were cultured from 16 of the pigeons trapped from the Delhi University Campus, and killed after 30 day's captivity.

For isolation of $C$. neoformans from pigeon excreta, a sample of about $4 \mathrm{~g}$ was suspended in $25 \mathrm{ml}$ of normal saline in a test-tube and shaken manually for 3-5 min. After allowing the sample to stand for about $40 \mathrm{~min}$., $5 \mathrm{ml}$ of the supernatant fluid was mixed with chloramphenicol $0.5 \mathrm{mg}$ per $\mathrm{ml}$, and incubated at $37^{\circ} \mathrm{C}$ for $1 \mathrm{~h}$. From 1 in 10 dilutions of this fluid, amounts of $0.1 \mathrm{ml}$ and $0.2 \mathrm{ml}$ were streaked on plates of Staib's medium in duplicate. For detection of $C$. neoformans in the atmosphere of the bird hospital, plates of Staib's medium were exposed for $5 \mathrm{~min}$. both inside and outside the cages on four occasions. The cultures were incubated at $25^{\circ} \mathrm{C}$ for 3 weeks before discarding them as negative.

Identification of isolates. A presumptive identification of $C$. neoformans was made on the basis of the characteristic tan to brown pigmentation of colonies on Staib's medium. Identification was subsequently confirmed by intraperitoneal pathogenicity tests in white mice and by a study of morphological and biochemical characteristics as described by van der Walt (1970).

Received 10 Jan. 1977; accepted 17 Nov. 1977.

J. MED. MICROBIOL.-VOL. 11 (1978) 


\section{RESULTS}

Cryptococcus neoformans was cultured from the crop of four $(1.3 \%)$ of 319 pigeons investigated (table I). The positive pigeons came from the Charity Bird Hospital, Delhi; three of them represented a group of 145 caged pigeons and one was from a group of 141 pigeons kept free in the rooms. One pigeon yielded two $C$. neoformans colonies on culture and the remaining three pigeons each yielded one. Exposure of plates in one of the hospital rooms revealed C. neoformans in the atmosphere (table II); the number of colonies per plate was low. After a thorough cleaning and painting of the entire bird hospital, C. neoformans, could no longer be isolated from the atmosphere. The three attendants working in the bird hospital did not manifest any respiratory symptoms and oropharyngeal washings taken on three separate occasions from each failed to yield $C$. neoformans on culture.

None of the 69 specimens of crop washings from 33 free-living pigeons trapped from the University of Delhi Campus yielded $C$. neoformans. When portions of the contents of the proventriculus, gizzard, small intestine, large intestine and crop were cultured from 16 of these pigeons, the results were again negative. The organism was isolated from $55.4 \%$ and $69.2 \%$ of specimens of old excreta examined from the Bird Hospital and from the Arts Faculty Building, University of Delhi, respectively (table III).

\section{Discussion}

The isolations of $C$. neoformans from the crops of pigeons were sporadic and did not indicate a natural reservoir. The results are consistent with the rarity of reports of isolations

TABLE I

Isolation of Cryptococcus neoformans from the crops of pigeons

\begin{tabular}{l|rll} 
Pigeon populations studied & $\begin{array}{c}\text { Number of } \\
\text { pigeons }\end{array}$ & Specimens & $\begin{array}{c}\text { Number of positive specimens/ } \\
\text { number examined }\end{array}$ \\
\hline $\begin{array}{l}\text { Charity Bird Hospital, } \\
\text { Chandni Chowk, Delhi } \\
\text { Caged pigeons }\end{array}$ & 145 & Crop swabs & $3 / 145(2 \cdot 1 \%)$ \\
$\quad$ Free pigeons & 141 & Crop swabs & $1 / 141(0 \cdot 7 \%)$ \\
Delhi University Campus & 33 & Crop washings & $0 / 69$ \\
$\quad$ Total & 319 & & $4 / 355(1 \cdot 1 \%)$ \\
\hline
\end{tabular}

TABLE II

Frequency of recovery of Cryptococcus neoformans from the air in a Charity Bird Hospital

\begin{tabular}{c|cc}
$\begin{array}{c}\text { Date of exposure } \\
\text { of plates* }\end{array}$ & \multicolumn{2}{|c}{$\begin{array}{c}\text { Number of positive plates out of } 10 \\
\text { exposed }\end{array}$} \\
\hline & $\overbrace{\text { outside the cages }}^{\text {inside the cages }}$ \\
6 May 1975 & 4 & 8 \\
11 May 1975 & 5 & 7 \\
18 May 1975 Nov. 1976† & 3 & 7 \\
\hline
\end{tabular}

* An exposure time of $5 \mathrm{~min}$. was used.

$\dagger$ The hospital had been freed from the pigeon excreta, cleaned and painted. 
TABLE III

Isolation of Cryptococcus neoformans from pigeon excreta

\begin{tabular}{l|lc}
\hline \multicolumn{1}{c|}{ Locality } & \multicolumn{1}{c}{ Type of sample } & $\begin{array}{c}\text { Number of positive samples/ } \\
\text { number examined }\end{array}$ \\
\hline $\begin{array}{c}\text { Charity Bird Hospital, } \\
\text { Chandni Chowk, Delhi }\end{array}$ & $\begin{array}{c}\text { Thick layers of old } \\
\text { and dry excreta inside } \\
\text { cages } \\
\text { Fresh excreta }\end{array}$ & $31 / 56(55 \cdot 4 \%)$ \\
$\begin{array}{c}\text { Delhi University Campus } \\
\text { Arts Faculty Building } \\
\text { Heaps of old excreta } \\
\text { with dust and feathers } \\
\text { from inside a tower } \\
\text { Fresh excreta from } \\
\text { trapped pigeons }\end{array}$ & $0 / 40$ \\
\hline
\end{tabular}

of $C$. neoformans from the gastrointestinal tract of pigeons (Weiland, Böhm and Abdallah, 1968) and inability of the organism to persist after it was fed experimentally (Littman and Borok, 1968; Sethi and Randhawa, 1968). The low frequency of isolation (1.3\%) of $C$. neoformans from the pigeon crop in the present study is in sharp contrast to its recovery from nearly $50 \%$ of pigeons by Swinne-Desgain (1974) who inferred that the pigeon was a reservoir. This opinion was revised subsequently (Swinne-Desgain, 1975). The wide differences in the recovery of $C$. neoformans from the pigeon crop in the two studies may have been the result of different degrees of environmental contamination.

\section{SUMMARY}

Cryptococcus neoformans was found in the crops of four (1.3\%) of 319 pigeons in the Charity Bird Hospital and the University Campus, Delhi. It was demonstrated repeatedly at the Bird Hospital in old pigeon excreta as well as in the air. The findings substantiate the current view that the pigeon itself is not a reservoir of $C$. neoformans although it may serve as a carrier of the fungus.

We express our sincere thanks to Mr T. Kowshik for technical assistance and to the staff of the Charity Bird Hospital, Delhi, for their co-operation.

\section{REFERENCES}

AJello, L. 1967. Comparative ecology of respiratory mycotic disease agents. Bact. Rev., $31,6$.

Emmons, C. W. 1955. Saprophytic sources of Cryptococcus neoformans associated with the pigeon (Columba livia). Am. J. Hyg., 62, 227.

Gugnani, H. C., Gupta, N. P. and Shrivastav, J. B. 1972. Prevalence of Cryptococcus neoformans in Delhi Zoological Park and its recovery from the sputum of an employee. Indian J. med. Res., 60, 182.

Gustin, P. N. AND Kelley, D. C. 1971. A survey of zoo aviaries for the presence of Histoplasma capsulatum and Cryptococcus neoformans. Mycopathologia, 45, 93.

LitTMAN, M. L. AND BoroK, R. 1968. Relation of the pigeon to cryptococcosis. Natural carrier state, heat resistance and survival of Cryptococcus neoformans. Mycopathologia, $35,329$.

PaL, M. 1975. A study of cryptococcosis with special reference to its epidemiology. M.V.P.H. Dissertation, Calcutta University, India. 
Partridge, B. M. AND Winner, H. I. 1965. Cryptococcus neoformans in bird droppings. Lancet, 2, 1251.

Randhawa, H. S., Clayton, Y. M. AND Riddell, R. W. 1965. Isolation of Cryptococcus neoformans from pigeon habitats in London. Nature, Lond., 208, 801.

Randhawa, H. S., Staib, F. AND BlisSe, A. 1973. Observations on the occurrence of Cryptococcus neoformans in an aviary, using niger seed creatinine agar and membrane filtration technique. Zentbl. Bakt. ParasitKde, Abt. II, 128, S795.

Sethi, K. K. AND Randhawa, H. S. 1968. Survival of Cryptococcus neoformans in the gastrointestinal tract of pigeons following ingestion of the organism. J. infect. Dis., 118, 135.

Swinne-Desgain, D. 1974. The pigeon as reservoir for Cryptococcus neoformans. Lancet, 2,842 .

Swinne-Desgain, D. 1975. Cryptococcus neoformans of saprophytic origin. Sabouraudia, $13,303$.

WALT, VAN DER, J. P. 1970. Criteria and methods used in classification. In The yeasts, 2nd ed., edited by J. Lodder, Amsterdam, p. 34.

Weiland, E., BöHm, K. H. and Abdallah, I. S. 1968. Zum Vorkommen von Cryptococcus neoformans in Tauben. Berl. Münch. tierärtzl. Wschr., 81, 409. 